\title{
How Does Credit Supply React to a Natural Disaster? Evidence from the Indian Ocean
}

\section{Tsunami}

\author{
Linh Nguyen ${ }^{\mathrm{a}}$ and John O.S. Wilson ${ }^{\mathrm{a},{ }^{*}}$
}

\begin{abstract}
The supply of credit may increase or decrease following a natural disaster, depending on the extent to which banks can absorb risk, and the economic prospects and demand for finance by affected firms and households. In this paper, we assess the impact of a natural disaster (Indian Ocean Tsunami of 2004) on the aggregate supply of credit to provinces throughout Thailand. The results of our investigation suggest that the tsunami has long-lasting negative effects on bank lending, albeit the effects are spread unevenly across geographic areas with most of the reduction in aggregate lending occurring in severely affected provinces. We also find that the presence of bank branches in affected regions mitigates some of the adverse lending effects that follow the tsunami.
\end{abstract}

Keywords: Bank lending; Credit supply; Difference-in-differences; Indian Ocean tsunami; Natural Disaster; Thailand.

JEL classification: G21, G28

\footnotetext{
${ }^{a}$ Centre for Responsible Banking \& Finance, School of Management, Gateway Building, University of St Andrews, St Andrews, Fife, KY16 9RJ, Scotland, UK. Email: 1hn2@st-andrews.ac.uk (Linh H. Nguyen); jsw7@st-andrews.ac.uk (John O.S. Wilson). We are grateful to Ross Brown, Leo de Haan, Iftekhar Hasan, Neil Lee, José Liñares-Zegarra, Phil Molyneux, Louis Nguyen, Daniel Oto-Peralías, Bert Scholtens and Jon Williams for various helpful comments. The usual disclaimer applies.

*Corresponding author
} 


\section{Introduction}

In this paper, we investigate the effects of a sudden and rare natural disaster on bank lending. Prior evidence suggests that sudden adverse natural events such as hurricanes, volcanic eruptions, earthquakes and floods impact negatively on economic growth (Cavallo et al. 2013; Strobl 2011). Bank credit is an important driver of economic growth because it is the predominant source of finance to firms and households in most countries (Allen, Carletti, and Gu 2015). Disruptions to the flow of bank credit are likely to affect the ease with which firms and households can access finance, and ultimately lead to detrimental effects on the real economy (Cetorelli 2015).

Theory differs in predicting how bank lending responds to an adverse shock. Brei and Schclarek (2015) develop a model of bank lending in an economy with three main agents: banks, depositors and corporate borrowers. They posit that in a time of severe crisis, banks reduce lending and increase holdings of liquid assets due to the potential risk of depositor withdrawals and the increased risks associated with the investments of borrowers. Bos, Sanders and $\mathrm{Li}$ (2018) propose a dynamic asset allocation model to explain how banks react to natural disasters. The authors suggest that an increase in the risk of disaster leads to an increase in bank lending to meet the increased credit. When banks face capital constraints, lending declines and remaining resources are reallocated to less risky assets.

Prior evidence regarding whether bank lending increases or decreases following a natural disaster is rather mixed. Some studies show that banks decrease credit supplied to affected areas and increase their holdings of government securities (Choudhary and Jain 2017; Schüwer, Lambert, and Noth 2018). The decline in bank lending could arise from a decline in the value of collateral and the economic prospects of borrowing households and firms in affected areas, exposing bank balance sheets to unexpected losses. This reduces the capacity of banks to assume more risk via increased lending. Banks may also suffer from a reduction in 
capital and deposits, which reduces the funds available for lending. In contrast, other evidence suggests that bank lending increases in areas affected by natural disasters. Cortés and Strahan (2017), for instance, find that banks increase lending in areas affected by hurricanes by cutting lending in unaffected areas where banks do not have branches. Chavaz (2016) finds that banks with more branches in the hurricane-affected counties increase lending more than provinces with fewer branches.

The ambiguity of prior evidence motivates us to utilise a quasi-natural experiment in order to investigate how a natural disaster in the form of the Indian Ocean Tsunami (which struck on $26^{\text {th }}$ December 2004) impacts aggregate bank lending in the provinces of Thailand. Unlike other natural disasters (such as hurricanes) which arise from seasonal patterns in weather conditions or sudden changes in government fiscal and monetary policy (which take time to affect the financial system and real economy), tsunamis in the Indian Ocean are extremely rare, strike without warning and cause devastation across the geographic areas affected. We use this differential geographic impact to overcome identification concerns, and investigate whether there is a causal link from a natural disaster to the aggregate lending of banks. Given that a tsunami represents an exogenous shock, any subsequent observed changes in credit supply are likely to be caused by the shock, and not by coincident changes in other relevant economic variables.

This study is also motivated by the fact that the impact of a natural disaster on bank credit and the wider economy depends on the institutional frameworks and level of financial development of areas affected (Kahn 2005; Kellenberg and Mobarak 2011). Evidence suggests that countries with a developed insurance market suffer less following a natural disaster (Melecky and Raddatz 2015). In the absence of insurance to share and consequently mitigate risk, affected households and firms have to rely on banks as an alternative source of financing 
for economic recovery. This provides another justification for our investigation of the impact of natural disasters on bank credit supply. ${ }^{1}$

The dataset used in the present study comprises information on selected items of commercial bank balance sheets at an aggregate provincial level held at the Bank of Thailand, and monetary damage and loss estimates associated with the tsunami held at the Asian Disaster Preparedness Centre. Based on the theoretical insights of Brei and Schclarek (2015), we propose three hypotheses for empirical testing. The first hypothesis contends that following the tsunami, aggregate bank lending declines in affected provinces. The second hypothesis contends that following the tsunami, aggregate lending in severely affected provinces declines more significantly than in the mildly affected provinces. Finally, the third hypothesis contends that following the tsunami, there is a long-lasting impact on aggregate bank lending.

In order to test these hypotheses, we use a difference-in-differences (DiD) approach of the type used in prior studies to investigate the differential effects on credit supply of: natural disasters (Cortés and Strahan 2017); financial crises (Chava and Purnanandam 2011); and regulatory interventions (Berger, Roman, and Sedunov 2016). The DiD approach does not require data at individual bank level, and is relatively simple to employ using aggregate data of the form utilised in the current study. Moreover, this approach avoids endogeneity issues present when comparing heterogeneous entities, given that the influence of unobserved timeconstant effects on the outcome variable have been eliminated through differencing (Bertrand, Duflo, and Mullainathan 2004). Therefore, the DiD approach is valuable for evaluating causal

\footnotetext{
${ }^{1}$ Most studies on disasters and bank credit tend to concentrate on developed countries, particularly the US, where various forms of ex-ante risk mitigation (such as insurance protection) and ex-post official responses (including official government financial assistance schemes) are more prevalent. Due to the lack of detailed data on the level of insurance payout, government financial assistance and foreign aid at provincial level, we are unable to verify empirically the financial support to regions following the tsunami. However, similar to other developing countries, insurance coverage against disasters in Thailand is limited (Asian Disaster Preparedness Centre, 2006). In contrast to the US, where typically $50 \%$ of losses were covered by insurance payments (e.g. Hurricane Andrew in 1992 and the Northbridge earthquake in 1994), only $15 \%$ of the losses from the Indian tsunami 2004 were covered by insurance (Ferguson 2006). In terms of government support, in the US, disaster-affected households receive direct monetary support from the Federal Emergency Management Agency (FEMA). No support is readily accessible in Thailand (Asian Disaster Preparedness Centre, 2006).
} 
effects. Furthermore, the DiD approach is appropriate when a shock produces an immediate effect on the outcome variable of interest (which is likely to be the case for the 2004 Indian Ocean tsunami event used in the present study).

The results of the empirical analysis suggest that following the tsunami, aggregate bank lending declines in affected provinces compared to unaffected provinces. These effects are spread unevenly across geographic regions with most of the reduction in aggregate lending occurring in provinces most affected by the tsunami. Moreover, the tsunami has a long-lasting negative effect on aggregate bank lending, which dissipates after an extended period (of 22 months). We also find that the number of bank branches located in affected regions mitigates some of the adverse effects on credit supply following the tsunami.

We contribute to the growing literature on the impact of natural disasters on bank credit supply. We complement prior theoretical contributions that predict a negative effect of disasters on bank lending (Brei and Schclarek 2015). We find that the reduction in bank credit supply differs significantly between geographic regions depending on the severity of the exogenous shock (Bos, Sander, and Li 2018). Moreover, we find that the physical presence of banks in affected areas fosters the flow of credit. This supports the findings of prior research which suggest that banks with a physical presence (number of branches) in distaster affected areas increase lending more than provinces with a lower physical presence (Chavaz 2016).

Second, we augment prior evidence on the impact of exogenous events on bank aggregate lending. Previous studies show that disruptions to aggregate bank lending have a significant impact on firm investment and economic growth (Amiti and Weinstein 2018; Peek, Rosengren, and Tootell 2003). We show that a sudden natural disaster can have a long-lasting effect on aggregate bank lending. As such, we provide evidence on the impact of a rare disaster on aggregate bank lending in a setting where banks act as the primary source of financing for firms and households. The evidence from our analysis of aggregate bank lending also 
complements prior research that uses micro-level (loan) data to assess the impact of exogenous shocks to bank credit supply. For example, Jiménez et al. (2012) show that strict monetary policy and deteriorating economic conditions reduce the provision of bank credit.

Third, we augment a handful of recent bank-level studies, which show that natural disasters impact credit supply in developed economies (Chavaz 2016; Cortés and Strahan 2017; Garmaise and Moskowitz 2009; Hosono et al. 2016; Schüwer, Lambert, and Noth 2018). ${ }^{2}$ In the current context, we present evidence of the impact of a natural disaster in a developing economy where insurance protection and official financial assistance (which can act as mechanisms for risk transfer and augment the capacity of borrowers to cope with unexpected events) are limited. In the absence of such mechanisms, it is likely that households and firms in affected areas would have to turn to banks as a major financing source for recovery after disasters. This would signify the positive role that bank credit plays in any economic recovery following a natural disaster (Becchetti and Castriota 2011; De Mel, McKenzie, and Woodruff 2012).

The remainder of this paper is structured as follows. Section 2 provides a background and context to the present study. In Section 3, we discuss the data set used and provide a descriptive analysis of aggregate bank lending. Section 4 outlines the estimable model and presents the results of the empirical analysis. In Section 5, we execute a battery of additional tests in order to check the robustness of the main results presented in S ection 4 . Section 6 concludes.

\section{Background}

\footnotetext{
${ }^{2}$ Basker and Miranda (2018) focus on how a severe weather shock affects smaller firms that rely on more informal forms of finance such as loans from friends and family and even credit-card debt. They find that smaller and less productive firms that incurred physical damage during hurricane Katrina were less likely to survive.
} 
Tsunamis occur following large-scale disturbances in the ocean. The most common cause is an earthquake under the sea, which creates an explosive vertical motion leading to a sudden rise and fall of the sea level. Major tsunamis are generated by earthquakes with magnitudes exceeding 7.0 on the Richter scale and which take place less than 30 kilometres beneath the surface of the earth. The resulting tsunami propagates as a series of waves, which involve the movement of water all the way to the sea floor. In the open ocean, a tsunami is barely noticeable. However, as a tsunami approaches the coastline, the wave height and the speed of the current increase dramatically. The resulting waves can reach up to 30 metres high and last for several hours. ${ }^{3}$

On $26^{\text {th }}$ December 2004 , a powerful earthquake measuring 9.1 on the Richter scale, with its epicentre just off the Northern part of Sumatra, Indonesia, created a tsunami that affected many countries from Asia to Africa. The unexpectedness of the tsunami and the lack of prior warning meant that the devastation and fatalities were spread throughout countries around the Indian Ocean. Within two hours, the tsunami had claimed over 63,000 lives in Thailand, Sri Lanka and India (Bernard et al. 2006). In Thailand (the geographic focus of the present study), the tsunami killed 8,000 people and caused severe damage to property, fishing vessels, housing, infrastructure and agricultural crops. ${ }^{4}$ The tsunami flooded coastal areas two to three kilometres inland. The affected areas (shown in Figure 1) were contaminated with salt water to the detriment of agricultural production and water quality (UNEP 2005). There were sizeable declines in the productive capacity of the real economy. According to estimates reported by the Asian Disaster Preparedness Centre, the two most affected industries

\footnotetext{
3 See: NOAA at http://wcatwc.arh.noaa.gov/?page=tsunami_science; Australian Bureau of Meteorology at http://www.bom.gov.au/tsunami/info/faq.shtml

${ }^{4} 14$ countries were affected by the tsunami. In descending order numbers of fatalities these were: Indonesia, Sri Lanka, India, Thailand, Somalia, the Maldives, Malaysia, Myanmar, Tanzania, Bangladesh, the Seychelles, South Africa, Yemen, and Kenya. We focus on Thailand because it was among the most severely affected countries, and because regional bank lending data is available at a relatively high frequency (monthly intervals) from the central bank. This enables us to capture the impact of the tsunami on bank lending in a timely fashion. Datasets for other affected countries are not available to us.
} 
(accounting for over $90 \%$ of total recorded losses) were tourism, with losses of THB71972 million, and fisheries, with losses of THB6481 million (Asian Disaster Preparedness Centre 2006).

[Figure 1 near here]

In Thailand, the geographic areas most affected by the tsunami were the six provinces in the south of the country, comprising Krabi, Phangnga, Phuket, Ranong, Satun and Trang. These six provinces are classified as affected areas in the present study. Table 1 provides a summary of the economic impact of the tsunami in these six affected areas. Overall, the cumulative economic impact accounted for approximately $50 \%$ of the total economic output of these provinces. However, most of the impact of the tsunami was concentrated in the Krabi, Phangnga and Phuket provinces. In these provinces, average losses and damages exceeded $75 \%$ of annual output. This is far higher than the recorded losses (of less than $10 \%$ of annual output) in the Ranong, Satun and Trang provinces.

[Table 1 near here]

\section{Data and descriptive analysis}

We collect data on damages and losses incurred in the 75 Thai provinces from the Asian Disaster Preparedness Centre. This dataset is assembled using a disaster assessment methodology developed by the United Nations Economic Commission for Latin America and the Caribbean.

We collect data on aggregate bank deposits and loans at monthly frequency from the statistics of financial institutions produced by the Bank of Thailand (Bank of Thailand 2015). 
This data source provides data on selected items of commercial bank balance sheets and the number of bank branches at provincial level in 75 provinces located within four geographic regions (Central, Northern, North-eastern and Southern). An obvious limitation of this aggregate data is that it does not allow us to investigate how lending behaviour changes across individual banks. However, the relatively high frequency of aggregate data does allow us to construct a panel at monthly (rather than quarterly or yearly) intervals, and capture the effects of the tsunami on bank lending in a timely fashion.

\section{Classification of affected provinces}

We partition the geography of Thailand into affected and unaffected provinces based on the extent of monetary damages and losses estimates compiled by the Asian Disaster Preparedness Centre. Six provinces (shown in Table 1) are classified as affected, while the remainder are unaffected. In order to test if any change in bank lending is sensitive to the severity of destruction recorded, we partition the affected provinces further into two groups. The severely affected group (Krabi, Phangnga and Phuket) includes provinces in which the impact (measured as the ratio of the monetary value of damages and losses to province-level domestic product in the previous year) was above the average for all affected provinces. Areas where the impact was below the average for all affected provinces form the mildly affected group (Ranong, Satun and Trang).

\section{Descriptive analysis}

A descriptive summary of the variables used in the empirical analysis is presented in Table 2. The time horizon is 24 months around the date of the tsunami. The main (dependent) variable of interest is 'loan growth' measured as the percentage monthly change in aggregate bank lending in a given province. Across the three groups of provinces (severely affected, 
mildly affected, unaffected), loan growth is lowest in the severely affected group. Moreover, loan growth in this group is volatile, evidenced by a much higher standard deviation, and a far larger gap between the minimum and maximum growth rates in lending than those calculated for the mildly affected and unaffected groups. This volatility is likely to reflect the contrast in lending growth pre- and post-tsunami.

We do not observe similar patterns in other variables. Average 'deposit' in severely affected areas is higher than the averages of other provinces. This reinforces our expectation that any decline in lending is not caused by a change in bank deposits.

\section{[Table 2 near here]}

A preliminary analysis of the evolution of bank lending in severely affected, mildly affected and unaffected provinces before and after the tsunami is shown in Figure 2. In the 12 months prior to the tsunami, there is a similar pattern in bank lending growth across provinces. Aggregate bank lending in severely affected provinces is significantly higher than that in mildly affected and unaffected provinces. There was a parallel trend in bank lending growth in these three areas for several months prior to the tsunami. ${ }^{5}$

Following the tsunami, the growth of aggregate bank lending in the severely affected provinces falls below that to areas unaffected by the Tsunami. In severely affected provinces aggregate bank lending declines to a record low in the two months following the tsunami. In contrast, aggregate bank lending in mildly affected provinces does not show a significant change after the tsunami. Overall, our descriptive analysis suggests that following the tsunami,

\footnotetext{
${ }^{5}$ In using the difference-in-difference approach (outlined in Section 4), we assume that the trend in aggregate lending is similar for both affected and unaffected provinces in the pre-shock period. This is supported by Figure 2. In Section 5, we conduct robustness tests to check the reliability of our main findings in relation to this assumption.
} 
aggregate lending changes dramatically in the severely affected areas, but not in the mildly affected and unaffected provinces.

[Figure 2 near here]

In order to assess whether the difference in aggregate lending between affected and unaffected groups is statistically significant, we first classify the 75 provinces into affected and unaffected groups, and into pre- and post-tsunami periods (measured at monthly intervals). We then compare changes in aggregate loan growth within each group over time and across affected and unaffected groups. We expect a univariate test to yield a negative and significant coefficient for the difference in loan growth within the affected group, and an insignificant coefficient within the unaffected group. The coefficient for the difference across affected and unaffected groups should also be negative.

Table 3 presents the results. As expected, within the affected group of provinces, the coefficient (Diff1) is negative and statistically significant, suggesting that aggregate bank lending declines in the post-tsunami period. Within the unaffected group of provinces, however, the coefficient (Diff2) is approximately zero and insignificant, suggesting no difference in lending growth within this group before and after the tsunami. This suggests that aggregate bank lending in the affected provinces reacts negatively to the tsunami. It also allows us to rule out the possibility that (when drawing a comparison across the two groups) any lower growth in lending in the affected group is merely a reflection of an increase in lending in the unaffected provinces.

The coefficient for the difference across the affected and unaffected groups (Diff1Diff2) is negative and significant at the $1 \%$ level. This supports our hypothesis that bank lending declines after the tsunami. The larger standard deviation of loan growth in the affected 
provinces in the months following the tsunami is an additional indication of the negative impact of the tsunami on bank lending.

[Table 3 near here]

\section{Methods and results}

In order to explore the impact of the tsunami on aggregate bank lending, we conduct an empirical analysis as follows. First, we investigate the impact of the tsunami on aggregate bank lending across all affected provinces. This allows us to test formally our first hypothesis, which contends that following the tsunami, aggregate bank lending in affected provinces declines. Second, we partition the affected provinces into mildly and severely affected areas. This allows us to test directly our second hypothesis, which contends that following the tsunami, aggregate lending in severely affected provinces declines more significantly than in mildly affected provinces. Third, we investigate our third hypothesis which contends that following the tsunami, there is a lasting impact on aggregate bank lending.

\section{Tsunami effects on bank lending}

In order to test our first hypothesis, we estimate the following model:

$$
\Delta L_{p,(t, t-1)}=\beta\left(\text { tsunami }_{p} \times \text { post }_{t}\right)+\sum_{n=1}^{3} \tau_{n} \boldsymbol{X}_{n, p, r,(t, t-1)}+\varphi_{p}+\omega_{t}+\varepsilon_{p, r, t}
$$

where $p$ denotes provinces, $r$ regions and $t$ months. The dependent variable $\Delta L_{p, t}$ is bank lending measured by the percentage change in aggregate outstanding loans of commercial banks in province $\mathrm{p}$ between month $\mathrm{t}$ and month ( $\mathrm{t}-1)$.

$\left(\right.$ tsunami $_{p} \times$ post $\left._{t}\right)$ is an interaction variable which is the product of a dummy variable for the tsunami affected areas (which equals one if affected and zero otherwise) and a 
dummy variable for the months after the tsunami (which equals one for months post-tsunami and zero otherwise). This variable captures the effects of the tsunami on bank lending growth. Given that the tsunami occurred on $26^{\text {th }}$ December 2004, January 2005 is the first month after the event. We estimate a baseline model using a 24-month time horizon ( $1^{\text {st }}$ January 2004 to $24^{\text {th }}$ December 2005) around the tsunami. $\beta$ is the key parameter of interest. $\beta<0$ implies that bank lending in affected provinces decreases following the tsunami compared to unaffected areas. $\beta>0$ implies the opposite.

$\boldsymbol{X}_{n, p, r,(t, t-1)}$ are the control variables. 'bank branch' is the natural logarithm of the number of branches of commercial banks in province $\mathrm{p}$ in month $(\mathrm{t}-1)$. The number of branches may impact on the aggregate level of bank loans extended to borrowers within a particular province (Chavaz 2016). Prior evidence suggests that despite advances in credit-scoring technologies (Filomeni et al. 2016), bank-borrower geographic proximity does matter in increasing the probability of commercial loan approval (Brevoort and Hannan 2006) at lower rates of interest (Degryse and Ongena 2005). This is particularly the case in developing countries, where soft information on borrowers and knowledge of local economic conditions play a significant role in the screening, processing and approval of loans (Agarwal and Hauswald 2010).

'deposit' denotes the percentage change in the aggregate deposits of commercial banks in province $\mathrm{p}$ between month $\mathrm{t}$ and $(\mathrm{t}-1)$. We control for the change in deposits given that this is the main source of bank liabilities used to finance assets, especially in developing countries. ${ }^{6}$

\footnotetext{
${ }^{6}$ In the 24-month time horizon around the tsunami, the loan-to-deposit ratio is approximately $90 \%$ on average. However, the inclusion of deposits as a control might lead to some potential issues because the tsunami could affect bank deposits, which in turn are correlated with loans (Atanasov and Black 2016). For example, if deposits decrease after the shock because firms and households withdraw cash from banks in order to cope with losses, this reduces the funds available for banks to make loans. This effect of the tsunami would not be picked up by the estimated $\beta$ coefficients. Alternatively, if deposits increase because firms and households cash out insurance and deposit the money into banks, while the reconstruction and repairs to fixed assets are completed, the estimated $\beta$ coefficients are likely to be overstated. The second possibility is less likely because insurance coverage in Thailand is rather limited. However, to check if these possibilities can cause the form of bias identified above, we run a difference-in-differences estimator in which deposits are considered as the outcome (instead of loans). The results
} 
As theory suggests a positive correlation between lending and deposits (Brei and Schclarek

2015), we expect that higher aggregate bank deposits are associated with more lending.

'trend' denotes percentage change in aggregate loans in region $r$ between month $t$ and (t-1). This variable is included to capture the pre-treatment parallel trend assumption associated with the difference-in-differences estimator (Atanasov and Black 2016). $\varphi_{p}$ and $\omega_{t}$ are province and month fixed effects. $\varepsilon_{p, r, t}$ is the error term. We estimate Equation (1) using OLS with robust standard errors clustered at province level. ${ }^{7}$

\section{Tsunami effects in mildly and severely affected areas}

The impact of a natural disaster on bank lending may vary according to the severity of the event in a given geographic area. Firms and households in mildly affected areas are likely to suffer less following a natural disaster given that the loan portfolios and risk-taking capacity of banks located in these areas are only partially affected. Consequently, aggregate bank lending is likely to decrease by a smaller amount in mildly affected relative to severely affected geographic areas. This is in line with theory, which predicts a decline in lending when banks face financial constraints because of the severity of natural disasters (Bos, Sanders, and Li 2018).

suggest no statistical differences in deposit growth between affected and unaffected provinces before and after the tsunami. These findings alleviate our aforementioned concerns.

7 An empirical challenge in our study is to isolate shocks to loan supply from shocks to the demand for credit. The use of province- and month-fixed effects in all of the regressions should absorb the demand effects. In interpreting the results from Equation (1), we assume that credit demand increased after the tsunami. This assumption is made on the following basis. First, earlier studies in developing countries find that credit demand increases after natural disasters (Berg and Schrader 2012; Czura and Klonner 2010). Second, given the extensive damage caused by the tsunami (as discussed in Section 2), it is reasonable to assume that demand for credit increases because firms and households require funds for reconstruction. If credit demand increases, changes in bank lending can be attributed to supply side considerations. In order to support our assumptions, empirically, we tried to control for demand side effects by including the number and value of investment projects of the corporate sector. The results (reported in Table A.1) are similar to those from the main estimation in Equation (1). However, because these data are for approved foreign investment projects only and thus do not fully reflect local credit demand, we use these variables as a robustness test only. Further research could usefully engage in compiling disaggregated data so as to establish the effects of a natural disaster on the supply of bank credit in developing countries. 
In order to investigate whether there is a differential impact of the tsunami on aggregate bank lending across affected areas, we divide affected provinces (based on the respective ratio of estimated damages and losses to total gross economic output of a given province in the year prior to the tsunami) into mildly and severely affected. We then investigate the impact of the tsunami on aggregate bank lending in severely and mildly affected provinces using Equation (2).

$$
\begin{aligned}
\Delta L_{p,(t, t-1)}= & \beta_{1}\left(\text { severe }_{p} \times \text { post }_{t}\right)+\beta_{2}\left(\text { mild }_{p} \times \text { post }_{t}\right)+\sum_{n=1}^{3} \tau_{n} \boldsymbol{X}_{n, p, r,(t, t-1)}+\varphi_{p}+\omega_{t} \\
& +\varepsilon_{p, r, t}
\end{aligned}
$$

$\left(\right.$ severe $_{p} \times$ post $\left._{t}\right)$ is the interaction between severely affected provinces (Krabi, Phangnga and Phuket) and the months following the tsunami. $\left(\right.$ mild $_{p} \times$ post $\left._{t}\right)$ is the interaction between mildly affected provinces (Ranong, Satun and Trang) and the months following the tsunami. The base category is the interaction between unaffected provinces and the months following the tsunami

Columns (1) and (2) of Table 4 summarise the results of estimating Equation (1). $\hat{\beta}$ is negative and statistically significant (similar to the results of our univariate analysis presented in Table 3). This implies that bank lending in affected provinces declines compared to unaffected provinces, and suggests that the tsunami produces an adverse impact on bank credit supply. Our finding contrasts with some recent bank-level evidence, which explores the impact of natural disasters on bank credit in developed economies (Chavaz 2016; Cortés and Strahan 2017), but is consistent with others (Choudhary and Jain 2017; Garmaise and Moskowitz 2009; Schüwer, Lambert, and Noth 2018). Overall, we show that a rare disaster (in the form of a tsunami) affects bank lending negatively.

Columns (3) and (4) in Table 4 present the results of testing our second hypothesis as specified in Equation (2). The results reveal differences in the extent to which the tsunami 
impacts on bank lending in different provinces. Specifically, the coefficient for the interaction between severely affected provinces and the post-tsunami period $\left(\hat{\beta}_{1}\right)$ is negative and significantly different from zero. This shows that the tsunami has an adverse impact on bank lending in severely affected provinces. The coefficient for the mildly affected provinces $\left(\hat{\beta}_{2}\right)$, (on the other hand) is insignificant, with a value close to zero. This indicates that bank lending in mildly affected provinces does not change relative to lending in provinces that were unaffected by the tsunami. In other words, the tsunami does not cause bank credit supply to change in less affected provinces. The difference between the two coefficients in terms of statistical significance suggests that the decline in aggregate bank lending is concentrated within severely affected provinces, and it is this that drives the observed decline in aggregate bank lending.

Turning to our control variables, the number of bank branches is positively related to bank lending. This result supports the view that physical proximity to borrowers allows banks to collect soft information, which can be processed effectively to increase lending (Agarwal and Hauswald 2010; Brevoort and Hannan 2006). Our results suggest that any negative effects of the tsunami on lending growth are mitigated by the presence of branches (through which banks can maintain lending relationships with borrowers after the disaster based on information collected previously). The result is consistent with the findings of Chavaz (2016) that banks with fewer branches in hurricane-affected counties reduce lending more than those with more branches. The coefficient on deposits is positive. This is unsurprising given that deposits are the predominant source of bank financing in developing countries. However, it is not statistically significant.

[Table 4 near here] 
In order to test the hypothesis that the tsunami causes a long-term impact on aggregate bank lending, we specify a model (Equation 3) where affected areas are divided into severely and mildly affected. The two parameters of interest are $\epsilon_{(t+m)}$ and $\pi_{(t+m)}$.

$$
\begin{gathered}
\Delta L_{p,(t+m)}=\epsilon_{(t+m)}\left(\text { severe }_{p} \times \text { post }_{(t+m)}\right)+\pi_{(t+m)}\left(\text { mild }_{p} \times \operatorname{post}_{(t+m)}\right) \\
+\sum_{n=1}^{3} \tau_{n} \boldsymbol{X}_{n, p, r,(t+m)}+\varphi_{p}+\omega_{(t+m)}+\varepsilon_{p, r,(t+m)}
\end{gathered}
$$

All variables are defined as in Equation (1) and Equation (2). In Equation (3), t represents the 12-month period prior to the occurrence of the tsunami; $\mathrm{m}$ represents each additional month following the tsunami until any effects dissipate. We anticipate a diminishing effect of the tsunami. As a result, $\epsilon_{(t+m)}$ and $\pi_{(t+m)}(\mathrm{m}=1,2,3, \ldots, \mathrm{d}$, where $\mathrm{d}$ is the month from which the impact of the tsunami dissipates) are expected to increase over time from a large negative value towards zero. In other words, we expect the difference in lending between the unaffected and affected provinces to decline as the effects of the shock diminish. There are d regressions to be estimated.

Figure 3 depicts the lasting impact of the tsunami on bank lending using the coefficients for the severely affected $\left(\epsilon_{(t+m)}\right)$ and mildly affected provinces $\left(\pi_{(t+m)}\right)$ from Equation (3). Consistent with our earlier results, bank lending in severely affected provinces declines significantly following the tsunami. The largest decline in aggregate bank lending in these provinces is recorded two months after the tsunami. The effects of the tsunami dissipate over time before disappearing completely after 22 months.

A slightly different trend is observed for mildly affected provinces, where there is an increase in lending in the three months following the tsunami. After three months, aggregate bank lending declines gradually. The difference in lending between mildly affected and 
unaffected provinces is negligible after 11 months. The evidence reveals that aggregate bank lending declines more in provinces where the tsunami causes more extensive damage.

[Figure 3 near here]

In summary, the results of our empirical analysis suggest that the Indian Ocean Tsunami significantly reduces aggregate bank lending in affected provinces. Further analysis suggests that the tsunami generates a long-lasting impact on (provincial) lending in the most severely affected areas for up to 22 months. This period is twice as long as that observed for developed economies (Cortés and Strahan 2017). This significantly longer-lasting impact is likely to reflect the differences between developing and developed countries regarding arrangements and support for mitigating disaster risk (Kellenberg and Mobarak 2011; Kahn 2005). The limited availability of risk-sharing mechanisms such as private insurance and various official financial assistance schemes may have hindered banks from supporting firms and households in tsunami-affected areas. The number of bank branches in contrast increases lending, which to some extent mitigates the overall decline in lending in affected provinces (Chavaz 2016).

\section{Robustness tests}

The results of our empirical analysis suggest that the Indian Ocean Tsunami had a significant negative impact on credit supply. Moreover, our findings suggest that the effects are distributed unevenly across geographic areas, with those most severely affected by the tsunami experiencing the largest declines in the supply of credit. In this section, we check the robustness of our estimates of the effects of the tsunami on aggregate bank lending to common problems inherent in the difference-in-differences approach. 


\section{Different time windows}

First, we investigate the sensitivity of our observed results to different time horizons. We narrow the original 24-month time horizon to 18 months, 12 months and six months, and then re-estimate Equation (2). The results (reported in Table A.2 of the Appendix) are consistent with the main findings above. Noticeably, the key coefficients for longer time horizons (Columns 1 and 2) have smaller magnitudes than those for shorter time horizons (Columns 5 and 6). This reflects the diminishing effects of the tsunami on bank lending over time.

\section{Placebo tests}

We test whether the estimated difference in aggregate bank lending between affected and unaffected provinces is attributable to the impact of the tsunami or whether, in fact, this arises from some other cause. In order to test this, we first falsify the date of the tsunami. This falsification disrupts the correct assignment of the tsunami date, but maintains the identity of the provinces affected by the tsunami. We also conduct a second test where we falsify the location of the affected provinces. In this test, the affected provinces are assigned incorrectly, while the actual date remains unchanged.

We re-run our estimation as shown in Equation (2). If the decline in bank lending is caused by an unobservable shock that either predates or coincides with the tsunami, we should still find a significant decline in bank lending. The results of these tests, reported in Table A.3 (falsified dates of the tsunami) and Table A.4 (falsified location of the affected provinces), provide strong evidence that the tsunami causes the observed changes in aggregate bank lending.

\section{Serial correlation}


An inherent limitation of the difference-in-differences method is the inconsistency of the standard error of the key estimate if the outcomes are serially correlated (Bertrand, Duflo, and Mullainathan 2004). This could be an issue in the present study given that we use a long time series of 24 months around the tsunami. In order to address this problem, we ignore the time series by averaging the variables across two separate, pre- and post-tsunami, periods, and re-estimating Equation (2). The results, shown in Table A.5, confirm our earlier findings.

\section{Parallel trend assumption}

A critical assumption underlying the difference-in-differences approach is that lending in affected and unaffected areas should follow a common trend in the absence of the tsunami. Even though visual evidence in Figure 2 lends some support to this assumption, we carry out two additional tests.

In the first test, a group of provinces neighboured with the affected provinces is used as a control group. These neighbouring provinces share common characteristics (in terms of cultural, socioeconomic factors) with the affected provinces. The results of this robustness test are shown in Table A.6. The main findings from our empirical analysis are once again supported.

In the second test, we create a matched sample as a control group based on a propensity score matching exercise. We use the predicted propensity scores and conduct a one-to-one nearest-neighbour matching without replacement to match the tsunami-affected provinces with unaffected provinces. The results from this estimation (reported in Table A.7) are also consistent with our main findings.

\section{Conclusion}


The supply of bank credit is of crucial importance for the health of the economy. This is especially the case in developing countries, where bank credit is the predominant source of finance to households and firms. To date, most studies that have investigated the effects of exogenous shocks on bank credit supply are confined to developed economies. The paucity of evidence for developing economies motivates the present study.

We exploit the Indian Ocean tsunami of December 2004 to investigate the effects of an exogenous shock to commercial bank lending in Thailand. We test a series of hypotheses. First, we examine whether aggregate lending in affected provinces decreases after a tsunami. Second, we investigate whether following a tsunami, the decline in lending in severely affected provinces is more significant than in mildly affected geographic areas. Finally, we investigate whether a tsunami generates a long-term effect on regional (provincial) bank lending.

Employing the difference-in-differences approach, we find that following the tsunami, there is a significant decline in the aggregate supply of credit to affected provinces. Among the affected areas, we find that the decline in lending in affected provinces is driven by changes taking place in provinces that were most severely affected by the tsunami. We also find that the presence of bank branches in affected regions mitigates some of the adverse lending effects that follow the tsunami. These results are robust to a variety of sensitivity checks and searches for alternative causes.

The results of this study have relevance for policymakers tasked with overseeing the smooth functioning of the banking system during normal and stressed periods. First, the lack of official government financial assistance is likely to be a key factor in explaining the severe and long-lasting effects of the tsunami on the overall credit supply to affected areas. Therefore, in the period immediately following a natural disaster, government agencies should prioritise resources to the most affected areas. These resources include the provision of direct financial support via cash payments, and loans to affected households and firms at preferential interest 
rates. Second, in the longer run, the government should develop a well-functioning private insurance market so that disaster risk can be shared across economic agents and thus, to some extent, mitigated. A highly penetrated insurance market would increase the number of firms and households to be covered by insurance and encourage banks to supply credit because insurance acts a safeguard against disaster losses and loan repayment failures. This would also help reduce the burden on public finances (which are likely to be more limited in developing countries). Third, banks should be incentivised to locate branches in areas vulnerable to disasters, so as to be better placed to provide funding to households and firms in the aftermath of natural disasters. 


\section{References}

Agarwal, Sumit, and Robert Hauswald. 2010. "Distance and Private Information in Lending." Review of Financial Studies 23 (7): 2757-2788. doi: 10.1093/rfs/hhq001.

Allen, Franklin, Elena Carletti, and Xian Gu. 2015. "The Role of Banks in Financial Systems." In Oxford Handbook of Banking, $2^{\text {nd }}$ edition by Allen N. Berger, Philip Molyneux, and John O. S. Wilson, 27-46. Oxford: Oxford University Press.

Amiti, Mary, and David E. Weinstein. 2018. "How Much Do Idiosyncratic Bank Shocks Affect Investment? Evidence from Matched Bank-Firm Loan Data." Journal of Political Economy 126 (2): 525-587. doi: 10.1086/696272.

Asian Disaster Preparedness Centre. 2006. The Economic Impact of the 26 December 2004 Earthquake and Indian Ocean Tsunami in Thailand. Bangkok: Department of Disaster Risk Management System.

Atanasov, Vladimir, and Bernard Black. 2016. "Shock-based Causal Inference in Corporate Finance and Accounting Research." Critical Finance Review 5 (2): 207-304. doi: $10.1561 / 104.00000036$.

Bank of Thailand. 2015. Statistics of Financial Institutions. Available at https://www.bot.or.th/English/Statistics/FinancialInstitutions/Pages/default.aspx.

Basker, Emek, and Javier Miranda 2018. "Taken by Storm: Business Financing and Survival in the Aftermath of Hurricane Katrina. " Journal of Economic Geography 18 (6): 12851313. doi:10.1093/jeg/lbx023.

Becchetti, Leonardo, and Stefano Castriota. 2011. "Does Microfinance Work as a Recovery Tool After Disasters? Evidence from the 2004 Tsunami." World Development 39 (6): 898912. doi: 10.1016/j.worlddev.2009.10.020. 
Berg, Gunhild, and Jan Schrader. 2012. "Access to Credit, Natural Disasters, and Relationship Lending." Journal of Financial Intermediation $21 \quad$ (4): $549-568 . \quad$ doi: 10.1016/j.jfi.2012.05.003.

Berger, Allen N., Raluca A. Roman, and John Sedunov. 2016. "Do Bank Bailouts Reduce or Increase Systemic Risk? The Effects of TARP on Financial System Stability." Working Paper No. 16-08, Federal Reserve Bank of Kansas City. Available at https://www.kansascityfed.org/ /media/files/publicat/reswkpap/pdf/rwp16-08.pdf?la=en.

Bernard, Eddie N., Harold O. Mofjeld, Vasily Titov, Costas E. Synolakis, and Frank I. González. 2006. "Tsunami: Scientific Frontiers, Mitigation, Forecasting and Policy Implications." Philosophical Transactions of the Royal Society of London A: Mathematical, Physical and Engineering Sciences 364 (1845): 1989-2007. doi: 10.1098/rsta.2006.1809.

Bertrand, Marianne, Esther Duflo, and Sendhil Mullainathan. 2004. "How Much Should We Trust Differences-In-Differences Estimates?" Quarterly Journal of Economics 119(1): 249275. doi: $10.1162 / 003355304772839588$.

Bos, Jaap, Mark Sanders, and Runliang Li. 2018. "Hazardous Lending: The Impact of Natural Disasters on Banks' Asset Portfolio." Maastricht University GSBE Research Memoranda No. 021. Available at https://cris.maastrichtuniversity.nl/portal/en/persons/jaapbos(6d417b64-e90f-4742-86d6-c540aab62d9c)/publications.html.

Brei, Michael, and Alfredo Schclarek. 2015. "A Theoretical Model of Bank Lending: Does Ownership Matter in Times of Crisis?." Journal of Banking and Finance 50: 298-307.

Brevoort, Kenneth P., and Timothy H. Hannan. 2006. "Commercial Lending and Distance: Evidence from Community Reinvestment Act Data." Journal of Money, Credit and Banking 38 (8): 1991-2012. 
Cavallo, Eduardo, Sebastian Galiani, Ilan Noy, and Juan Pantano. 2013. "Catastrophic Natural Disasters and Economic Growth." Review of Economics and Statistics 95 (5): 1549-1561. doi: 10.1162/REST_a_00413.

Cetorelli, Nicola. 2015. "Banking and Real Economic Activity." In Oxford Handbook of Banking, $2^{\text {nd }}$ edition, edited by Allen N. Berger, Philip Molyneux, and John O. S. Wilson, 807-822. Oxford: Oxford University Press.

Chava, Sudheer, and Amiyatosh Purnanandam. 2011. "The Effect of Banking Crisis on BankDependent Borrowers." Journal of Financial Economics 99 (1): 116-135. doi: 10.1016/j.jfineco.2010.08.006.

Chavaz, Matthieu. 2016. "Dis-integrating Credit Markets: Diversification, Securitization, and Lending in a Recovery." Staff Working Paper No. 617, Bank of England. Available at http://www.bankofengland.co.uk/research/Documents/workingpapers/2016/swp617.pdf.

Choudhary, M. Ali, and Anil Jain. 2017. "Finance and Inequality: The Distributional Impacts of Bank Credit Rationing." International Finance Discussion Papers 1211, Board of Governors of the Federal Reserve System. Available at https://www.federalreserve.gov/econres/ifdp/files/ifdp1211.pdf.

Cortés, Kristle Romero, and Philip E. Strahan. 2017. "Tracing Out Capital Flows: How Financially Integrated Banks Respond to Natural Disasters." Journal of Financial Economics 125 (1): 182-199. doi: 10.1016/j.jfineco.2017.04.011.

Czura, Kristina, and Stefan Klonner. 2010. " The Tsunami and the Chit Fund: Evidence from the Indian Ocean Tsunami Hit on Credit Demand in South India." Proceedings of the German Development Economics Conference, Hannover. Available at https://www.econstor.eu/bitstream/10419/39998/1/333_czura.pdf. 
De Mel, Suresh, David McKenzie, and Christopher Woodruff. 2012. "Enterprise Recovery Following Natural Disasters." Economic Journal 122 (559): 64-91. doi: 10.1111/j.14680297.2011.02475.x.

Degryse, Hans, and Steven Ongena. 2005. "Distance, Lending Relationships, and Competition." Journal of Finance 60 (1): 231-266. doi: 10.1111/j.1540-6261.2005.00729.x.

Ferguson, R. 2006. Insurance Solutions for Emerging Markets. Paper prepared for London Economic Forum, 5 December 2006.

Filomeni, Stefano, Gregory F. Udell, and Alberto Zazzaro. 2016. "Hardening Soft Information: How Far Has Technology Taken Us?" Working Paper No. 121. Available at http://docs.dises.univpm.it/web/quaderni/pdfmofir/Mofir121.pdf.

Garmaise, Mark J., and Tobias J. Moskowitz. 2009. "Catastrophic Risk and Credit Markets." Journal of Finance 64 (2): 657-707. doi: 10.1111/j.1540-6261.2009.01446.x.

Hosono, Kaoru, Daisuke Miyakawa, Taisuke Uchino, Makoto Hazama, Arito Ono, Hirofumi Uchida, and Iichiro Uesugi. 2016. "Natural Disasters, Damage to Banks, and Firm Investment." International Economic Review 57 (4): 1335-1370. doi: 10.1111/iere.12200.

Jiménez, Gabriel, Steven Ongena, José-Luis Peydró, and Jesús Saurina. 2012. "Credit Supply and Monetary Policy: Identifying the Bank Balance-Sheet Channel with Loan Applications." American Economic Review 102 (5): 2301-26. doi: 10.1257/aer.102.5.2301.

Kahn, Matthew E. 2005. "The Death Toll from Natural Disasters: The Role of Income, Geography, and Institutions." Review of Economics and Statistics 87 (2): 271-284. doi.org/10.1162/0034653053970339.

Kellenberg, Derek, and A. Mushfiq Mobarak. 2011. "The Economics of Natural Disasters." Annual Review of Resource Economics 3: 297-312. https://doi.org/10.1146/annurevresource-073009-104211. 
Melecky, Martin, and Claudio Raddatz. 2015. "Fiscal Responses after Catastrophes and the Enabling Role of Financial Development." World Bank Economic Review 29 (1): 129-149.

Peek, Joe, Eric S. Rosengren, and Geoffrey M. B. Tootell. 2003. "Identifying the Macroeconomic Effect of Loan Supply Shocks." Journal of Money, Credit and Banking 35 (6): 931-946.

Schüwer, Ulrich, Claudia Lambert, and Felix Noth. 2018. "How Do Banks React to Catastrophic Events? Evidence from Hurricane Katrina." Review of Finance. Forthcoming. doi.org/10.1093/rof/rfy010.

Strobl, Eric. 2011. "The Economic Growth Impact of Hurricanes: Evidence from U.S. Coastal Counties." Review of Economics and Statistics 93 (2): 575-589. doi: 10.1162/REST_a_00082.

UNEP (United Nations Environment Programme) 2005. After the Tsunami: Rapid Environmental Assessment. New York: UNEP. 


\section{Figure 1.1}

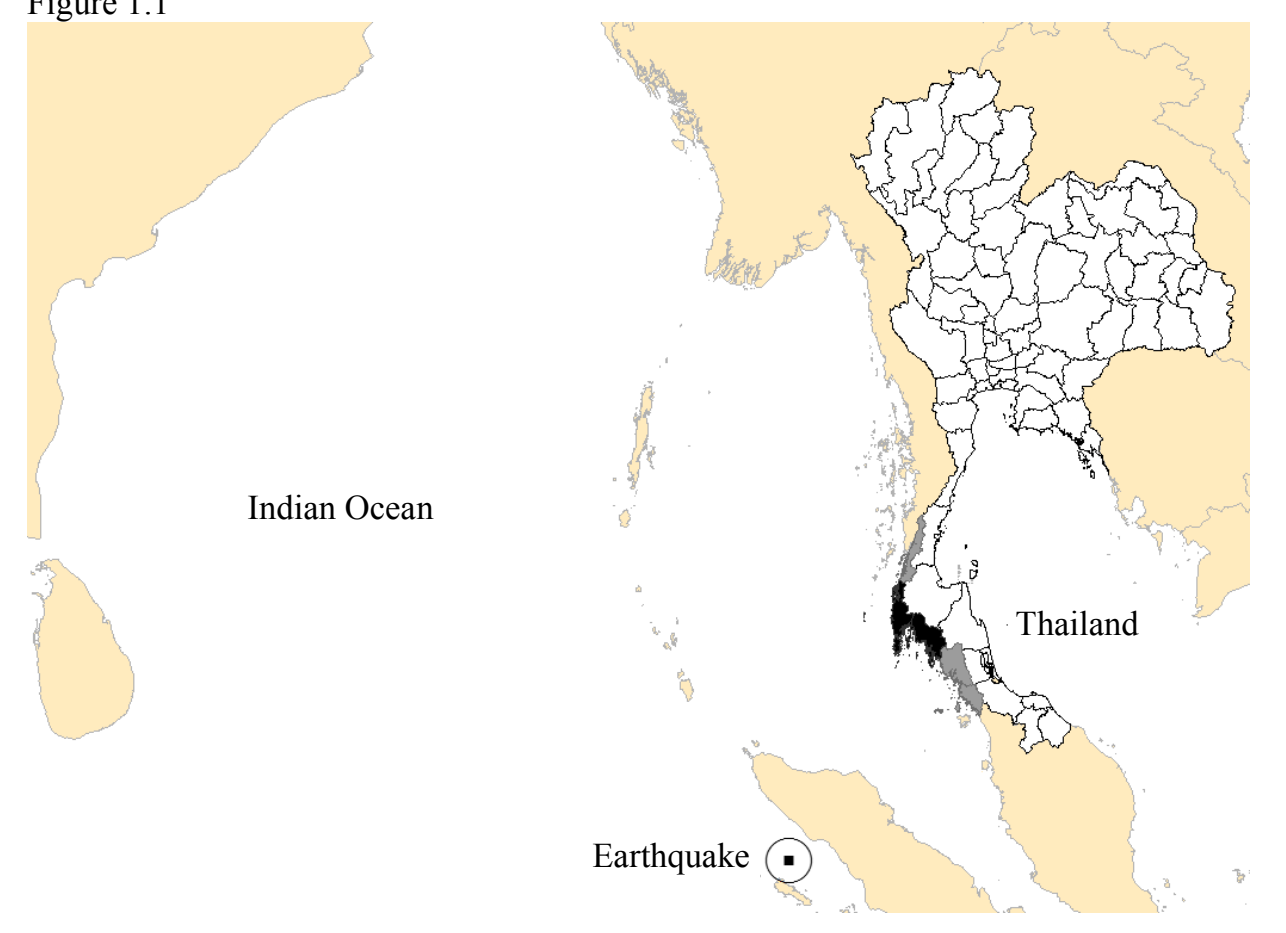

Figure 1.2

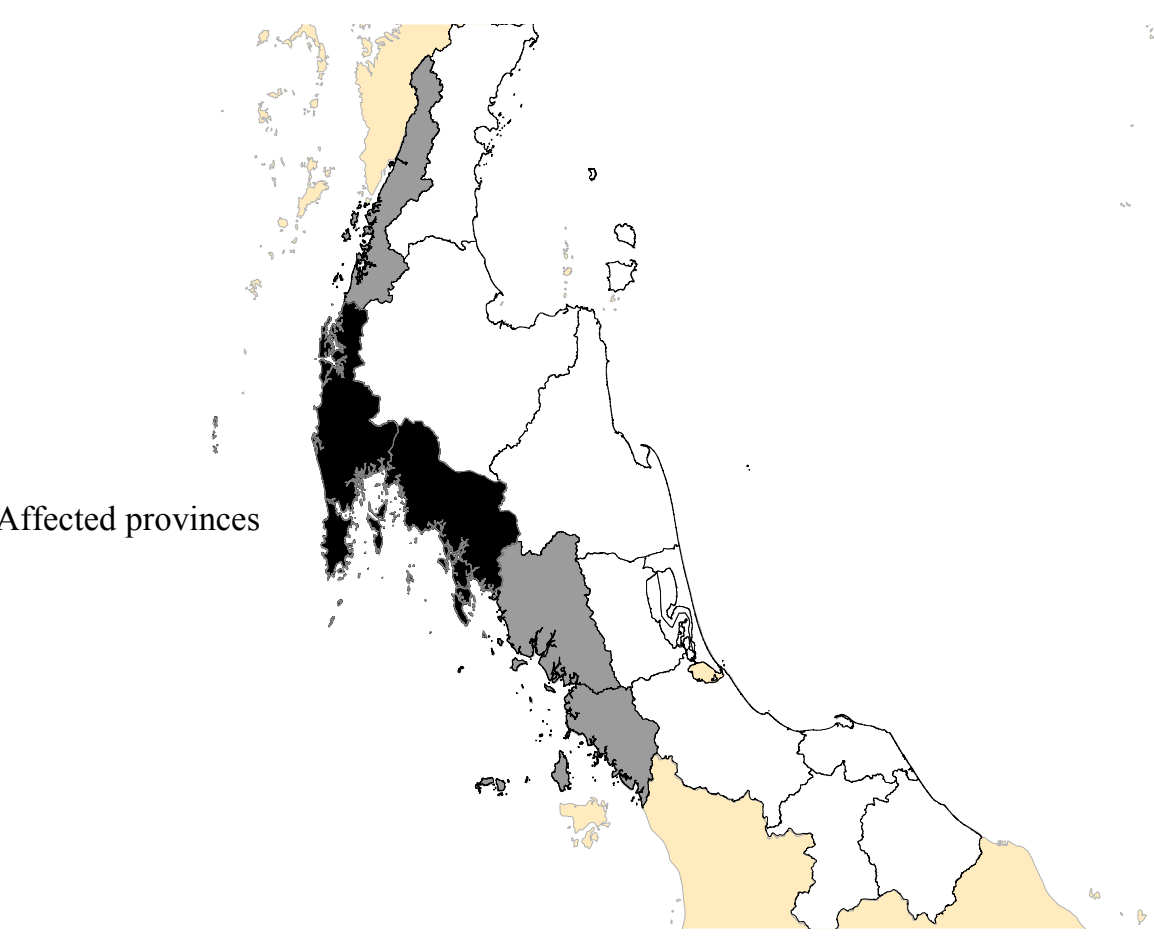

Notes: This figure presents the geographic location of provinces affected by the tsunami in Thailand based on data from the Asian Disaster Preparedness Centre (2006). Figure 1.1 shows the epicentre of the earthquake that generated the Indian Ocean tsunami on $26^{\text {th }}$ December 2004 and the geographic location of Thailand. Figure 1.2 highlights six provinces affected by the tsunami in the Southern region. The severely affected provinces are coloured black (Krabi, Phannga and Phuket) while mildly affected provinces (Ranong, Satun and Trang) are in (dark) grey. The unaffected locations are in white. The severity is classified based on estimated losses and damages over previous years' provincial domestic economic outputs as shown in Table 1. 


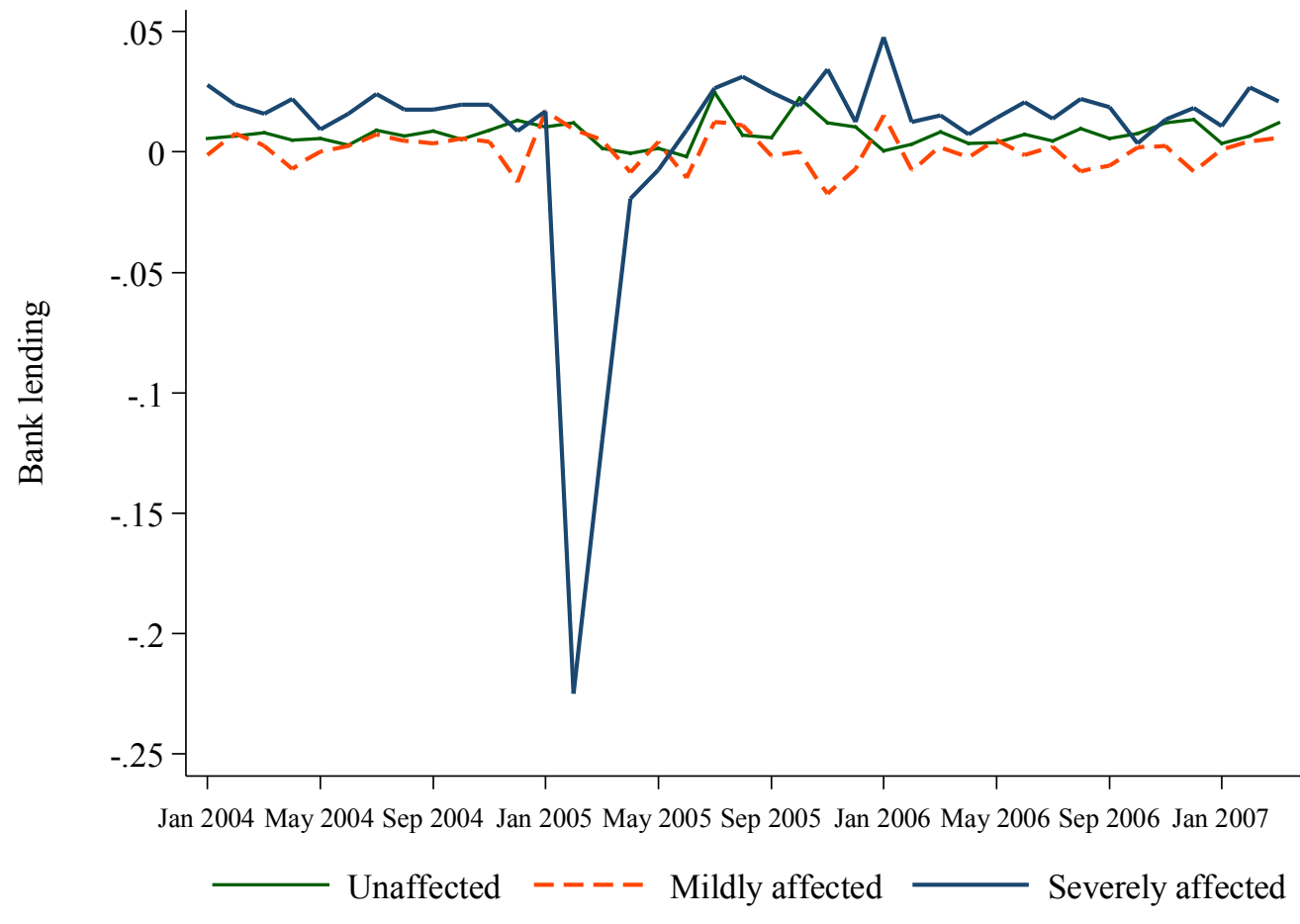

Notes: This figure compares changes in bank lending among the unaffected, mildly affected and severely affected provinces in Thailand after the Indian Ocean tsunami of $26^{\text {th }}$ December 2004. Bank lending is measured by the percentage change in aggregate bank loans in province $p$ between month $t$ and $(t-1)$. The provinces hit by the tsunami and severity are based on data from the Asian Disaster Preparedness Centre (2006). The unaffected areas are other provinces but exclude Bangkok. Further details are provided in Table 1. 
Figure 3. The longer term effects of the tsunami on aggregate bank lending

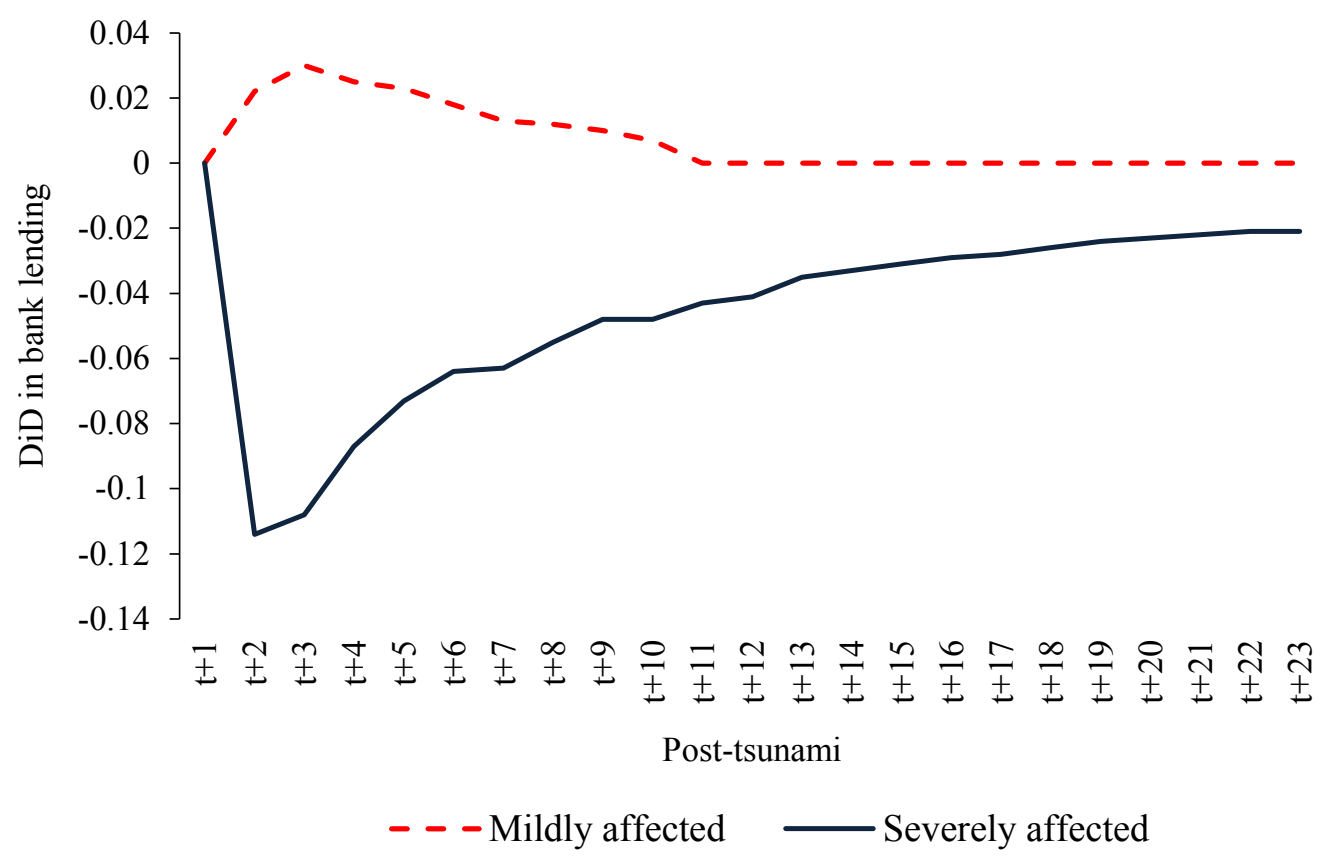

Notes: This figure shows the difference-in-differences (DiD) between bank lending in provinces affected and unaffected by the tsunami over $\mathrm{m}$ months after the tsunami $(\mathrm{m}=1,2,3, \ldots, 23)$. The difference is indicated by the regression coefficients $\epsilon_{m}$ (between severely affected and unaffected) and $\pi_{m}$ (between mildly affected and unaffected). These coefficients are estimated from Equation (3). The dependent variable is bank lending measured by the percentage change in aggregate bank loans in province $\mathrm{p}$ between month $\mathrm{t}$ and $(\mathrm{t}-1)$. The provinces hit by the tsunami and severity are based on data from the Asian Disaster Preparedness Centre (2006). The unaffected areas are other provinces but exclude Bangkok. Further details are provided in Table 1. 
Table 1. The economic impact of the tsunami in affected provinces

\begin{tabular}{llccc}
\hline Group & $\begin{array}{l}\text { Province } \\
\text { (by order of severity) }\end{array}$ & $\begin{array}{c}\text { Damage-to-GPP } \\
\text { ratio (\%) } \\
(1)\end{array}$ & $\begin{array}{c}\text { Loss-to-GPP ratio } \\
(\%) \\
(\%)\end{array}$ & $\begin{array}{c}\text { Impact-to-GPP } \\
\text { ratio (\%) } \\
(1)+(2)\end{array}$ \\
\hline Severely affected & Phuket & 10.4 & 79.7 & 90.1 \\
provinces & Krabi & 15.4 & 53.3 & 68.7 \\
& Phangnga & 42.0 & 25.9 & 67.9 \\
Mildly affected & Ranong & 4.2 & 12.0 & 16.2 \\
provinces & Satun & 3.4 & 2.8 & 6.2 \\
& Trang & 0.8 & 5.2 & 6.0 \\
\hline Average & Severely affected & 22.6 & 53.0 & 75.6 \\
& Mildly affected & 2.8 & 6.7 & 9.5 \\
& All-affected & 11.5 & 38.2 & 49.7 \\
\hline
\end{tabular}

Notes: This table presents the economic impact of the tsunami in Thailand. It is constructed based on data from Table 5.2 (p.21) in the report on the economic impact of the Indian Ocean tsunami in Thailand by the Asian Disaster Preparedness Centre (2006). The total impact is the cumulative damages and losses of three sectors: social sector (housing, education and health), production (agriculture, livestock, fisheries, industry, commerce and tourism), and infrastructure (water supply, electricity, transport and communications and others). The affected provinces are ranked in the order of severity, which is indicated by the total impact over the provincial economic outputs of the previous year. GPP denotes Gross Provincial Product. 
Table 2. Descriptive statistics

\begin{tabular}{lccrrr}
\hline Variable & Obs. & Mean & Std. Dev. & Min & Max \\
\hline Panel A. Unaffected provinces & & & & & \\
Loan growth & 1,656 & 0.0080 & 0.0219 & -0.2147 & 0.2140 \\
Bank branch & 1,656 & 3.3131 & 0.7134 & 2.0794 & 5.1240 \\
Deposit & 1,656 & 0.0064 & 0.0175 & -0.1476 & 0.1533 \\
Trend & 1,656 & 0.0112 & 0.0122 & -0.0486 & 0.0607 \\
\hline Panel B. Mildly affected provinces & & & & & \\
$\quad$ Loan growth & 72 & 0.0014 & 0.0152 & -0.0619 & 0.0464 \\
Bank branch & 72 & 2.7689 & 0.3932 & 2.4849 & 3.3322 \\
Deposit & 72 & 0.0067 & 0.0149 & -0.0279 & 0.0558 \\
Trend & 72 & 0.0123 & 0.0230 & -0.0486 & 0.0607 \\
\hline Panel C. Severely affected provinces & & & & & \\
Loan growth & 72 & 0.0009 & 0.0692 & -0.4707 & 0.0764 \\
Bank branch & 72 & 3.4213 & 0.4432 & 3.0445 & 4.2195 \\
Deposit & 72 & 0.0124 & 0.0169 & -0.0294 & 0.0620 \\
Trend & 72 & 0.0123 & 0.0230 & -0.0486 & 0.0607 \\
\hline
\end{tabular}

Notes: This table summarizes a statistical description of the variables used in our study. 'Loan growth' is used to measure bank lending and is defined as the percentage change in aggregate bank loans in province $p$ between month $\mathrm{t}$ and $(\mathrm{t}-1)$. 'Branch' is the natural logarithm of the number of branches in province $\mathrm{p}$ at month $\mathrm{t}$. 'Deposit' is the percentage change in aggregate bank total deposits in province $p$ between month $t$ and ( $t-1)$. 'Trend' is the percentage change in aggregate bank loans in region $r$ between month $t$ and ( $t-1)$. Aggregated bank data at province-level are obtained from the Bank of Thailand's statistics on financial institutions. Provinces affected by the tsunami are identified using data from the Asian Disaster Preparedness Centre (2006). The time horizon used is 24-month around the Indian Ocean tsunami, which occurred on $26^{\text {th }}$ December 2004. Table 1 and Figure 1 provide further details of the names and geographical locations of these provinces. 
Table 3. Differences pre- and post-tsunami in aggregate bank lending between affected and unaffected provinces: univariate analysis

\begin{tabular}{|c|c|c|c|c|c|c|c|}
\hline \multirow[b]{2}{*}{ Loan growth } & \multicolumn{3}{|c|}{ Affected provinces } & \multicolumn{4}{|c|}{ Unaffected provinces } \\
\hline & Post- & Pre- & $\begin{array}{c}\text { Diffl } \\
(=\text { Post }- \text { Pre })\end{array}$ & Post- & Pre- & $\begin{array}{c}\text { Diff2 } \\
(=\text { Post }- \text { Pre })\end{array}$ & (Diff1 - Diff2) \\
\hline Mean & -0.008 & 0.010 & $-0.018 * *$ & 0.009 & 0.007 & 0.002 & $-0.020 * * *$ \\
\hline Std. Dev. & 0.068 & 0.015 & & 0.026 & 0.016 & & \\
\hline Obs. & 72 & 72 & & 828 & 828 & & \\
\hline
\end{tabular}

Notes: This table reports univariate tests of the differences in lending (measured by loan growth) between affected and unaffected provinces in the pre- and post-tsunami periods. Loan growth is defined as the percentage change in aggregate bank loans in province $\mathrm{p}$ between month $\mathrm{t}$ and $(\mathrm{t}-1)$. Pre- and post-tsunami indicate the 12-month period before and after the tsunami on $26^{\text {th }}$ December 2004, respectively. The provinces hit by the tsunami are classified based on data from the Asian Disaster Preparedness Centre (2006). Further details are provided in Table 1. Diff1 (Diff2) is the difference in loan growth between the post- and pre-tsunami periods in affected (unaffected) provinces. $* * *$, and $* * *$ denote statistical significance at $10 \%, 5 \%$, and $1 \%$ level, respectively. 
Table 4. Differences pre- and post-tsunami in aggregate bank lending between affected and unaffected provinces: regression analysis

\begin{tabular}{lcccc}
\hline Dependent variable: Loan growth & $(1)$ & $(2)$ & $(3)$ & $(4)$ \\
\hline Loan in affected provinces x post-tsunami & $-0.022^{* *}$ & $-0.019^{*}$ & & \\
& $(0.011)$ & $(0.011)$ & & \\
Loan in severely affected x post-tsunami & & & $-0.043^{* * *}$ & $-0.041^{* * *}$ \\
& & & $(0.013)$ & $(0.013)$ \\
Loan in mildly affected x post-tsunami & & & -0.003 & 0.003 \\
& & & $(0.003)$ & $(0.004)$ \\
Bank branch & $0.058^{* * *}$ & $0.094^{* * *}$ & $0.070^{* * *}$ & $0.113^{* * *}$ \\
& $(0.017)$ & $(0.024)$ & $(0.017)$ & $(0.023)$ \\
Deposit & 0.026 & 0.006 & 0.021 & -0.000 \\
& $(0.026)$ & $(0.039)$ & $(0.026)$ & $(0.040)$ \\
Trend & $0.615^{* * *}$ & $0.746^{* * *}$ & $0.608^{* * *}$ & $0.748^{* * *}$ \\
& $(0.129)$ & $(0.234)$ & $(0.128)$ & $(0.234)$ \\
\hline Observations & 1,800 & 1,800 & 1,800 & 1,800 \\
R-squared & 0.224 & 0.238 & 0.237 & 0.252 \\
Province fixed effects & Yes & Yes & Yes & Yes \\
Month fixed effects & No & Yes & No & Yes \\
\hline
\end{tabular}

Notes: This table reports the difference-in-differences in bank lending in all-affected, severely-affected and mildly-affected against unaffected provinces. The dependent variable is loan growth measured as the percentage change in aggregate bank loans in province $p$ between month $t$ and $(t-1)$. The main independent variable of interest is the interaction between the tsunami-affected provinces and the months following the tsunami. The estimation is based on 24-month time horizon around the tsunami as shown in Equation (1) (results in Column 1 and 2) and Equation (2) (results in Column 3 and 4). Robust standard errors clustered at province level are in parentheses. *, **, and *** denote statistical significance at $10 \%, 5 \%$, and $1 \%$ levels, respectively. 


\section{Appendix}

Table A.1. Differences pre- and post-tsunami in aggregate bank lending between affected and unaffected provinces: controlling for demand side effects

\begin{tabular}{|c|c|c|c|c|}
\hline Dependent variable: Loan growth & $(1)$ & $(2)$ & (3) & (4) \\
\hline Loan in affected provinces $x$ post-tsunami & $\begin{array}{l}-0.022 * \\
(0.011)\end{array}$ & $\begin{array}{l}-0.018^{+} \\
(0.011)\end{array}$ & & \\
\hline Loan in severely affected $x$ post-tsunami & & & $\begin{array}{c}-0.045^{* * *} \\
(0.014)\end{array}$ & $\begin{array}{c}-0.042 * * * \\
(0.013)\end{array}$ \\
\hline Loan in mildly affected $x$ post-tsunami & & & $\begin{array}{c}-0.003 \\
(0.003)\end{array}$ & $\begin{array}{c}0.004 \\
(0.004)\end{array}$ \\
\hline Bank branch & $\begin{array}{c}0.072 * * * \\
(0.025)\end{array}$ & $\begin{array}{c}0.114 * * * \\
(0.036)\end{array}$ & $\begin{array}{c}0.091 * * * \\
(0.025)\end{array}$ & $\begin{array}{c}0.142^{* * *} \\
(0.032)\end{array}$ \\
\hline Deposit & $\begin{array}{c}0.002 \\
(0.031)\end{array}$ & $\begin{array}{l}-0.029 \\
(0.060)\end{array}$ & $\begin{array}{l}-0.005 \\
(0.032)\end{array}$ & $\begin{array}{l}-0.040 \\
(0.061)\end{array}$ \\
\hline Trend & $\begin{array}{c}0.589 * * * \\
(0.136)\end{array}$ & $\begin{array}{c}0.804^{* * *} \\
(0.281)\end{array}$ & $\begin{array}{c}0.578 * * * \\
(0.135)\end{array}$ & $\begin{array}{c}0.806 * * * \\
(0.280)\end{array}$ \\
\hline Corporate project & $\begin{array}{c}0.002 \\
(0.002)\end{array}$ & $\begin{array}{l}-0.000 \\
(0.003)\end{array}$ & $\begin{array}{c}0.002 \\
(0.002)\end{array}$ & $\begin{array}{l}-0.000 \\
(0.003)\end{array}$ \\
\hline Corporate investment value & $\begin{array}{c}0.000 \\
(0.001)\end{array}$ & $\begin{array}{c}-0.000 \\
(0.001)\end{array}$ & $\begin{array}{c}0.000 \\
(0.001) \\
\end{array}$ & $\begin{array}{c}-0.000 \\
(0.001)\end{array}$ \\
\hline Observations & 1,200 & 1,200 & 1,200 & 1,200 \\
\hline R-squared & 0.258 & 0.281 & 0.275 & 0.302 \\
\hline Province fixed effects & Yes & Yes & Yes & Yes \\
\hline Month fixed effects & No & Yes & No & Yes \\
\hline
\end{tabular}

Notes: This table reports the difference-in-differences in bank lending in all-affected, severely-affected and mildly-affected against unaffected provinces. The dependent variable is loan growth measured as the percentage change in aggregate bank loans in province $p$ between month $t$ and $(t-1)$. The main independent variable of interest is the interaction between the tsunami-affected provinces and the months following the tsunami. The estimation is based on 24-month time horizon around the tsunami as shown in Equation (1) (results in Column 1 and 2) and Equation (2) (results in Column 3 and 4). 'Corporate project' is the natural logarithm of the monthly number of new projects approved in a region. 'Corporate investment value' is the natural logarithm of the monthly value (in million THB) of total investment projects approved in a region. These data are obtained from the Office of the Board of Investment of Thailand. The number of observations drop because data on corporate investment are not available for the Central region (25 provinces). Robust standard errors clustered at province level are in parentheses. $*, * *$, and $* * *$ denote statistical significance at $10 \%, 5 \%$, and $1 \%$ levels, respectively. ${ }^{+}$denotes statistical significant at $10.5 \%$ level. 
Table A.2. Differences pre- and post-tsunami in aggregate bank lending between affected and unaffected provinces: different time horizons

\begin{tabular}{lcccccc}
\hline Dependent variable: Loan growth & $(1)$ & $(2)$ & $(3)$ & $(4)$ & $(5)$ & $(6)$ \\
\hline Loan in severely affected x post- & $-0.050^{* * *}$ & $-0.048^{* * *}$ & $-0.064^{* * *}$ & $-0.063^{* * *}$ & $-0.102^{* * *}$ & $-0.103^{* * *}$ \\
tsunami & $(0.017)$ & $(0.017)$ & $(0.020)$ & $(0.020)$ & $(0.028)$ & $(0.028)$ \\
Loan in mildly affected x post- & 0.004 & $0.009^{* *}$ & $0.016^{* *}$ & $0.018^{* * *}$ & $0.035^{* * *}$ & $0.034^{* * *}$ \\
tsunami & $(0.003)$ & $(0.004)$ & $(0.007)$ & $(0.006)$ & $(0.010)$ & $(0.010)$ \\
Bank branch & $0.077^{* * *}$ & $0.117^{* * *}$ & $0.078^{*}$ & $0.100^{* *}$ & 0.083 & 0.072 \\
& $(0.027)$ & $(0.034)$ & $(0.044)$ & $(0.046)$ & $(0.089)$ & $(0.088)$ \\
Deposit & -0.040 & -0.078 & $-0.132^{*}$ & $-0.170^{* *}$ & $-0.239^{* *}$ & $-0.294^{* * *}$ \\
& $(0.041)$ & $(0.056)$ & $(0.070)$ & $(0.072)$ & $(0.102)$ & $(0.108)$ \\
Trend & $0.677^{* * *}$ & $0.796^{* * *}$ & $0.871^{* * *}$ & $0.835^{* * *}$ & $0.845^{* * *}$ & $0.809^{* * *}$ \\
& $(0.155)$ & $(0.268)$ & $(0.256)$ & $(0.276)$ & $(0.259)$ & $(0.262)$ \\
\hline Observations & 1,350 & 1,350 & 900 & 900 & 450 & 450 \\
R-squared & 0.243 & 0.257 & 0.331 & 0.340 & 0.438 & 0.441 \\
Province fixed effects & Yes & Yes & Yes & Yes & Yes & Yes \\
Month fixed effects & No & Yes & No & Yes & No & Yes \\
\hline
\end{tabular}

Notes: This table reports the difference-in-differences in lending between affected and unaffected provinces using different windows around the tsunami. The dependent variable is loan growth measured as the percentage change in aggregate bank loans in province $p$ between month $t$ and $(t-1)$. The main independent variable of interest is the interaction between the tsunami-affected provinces and the months following the tsunami. The estimation is based on 18-month (results in Column 1 and 2), 12-month (results in Column 3 and 4) and six-month time horizon (results in Column 5 and 6) around the tsunami as shown in Equation (2). Robust standard errors clustered at province level are in parentheses. ${ }^{*}, *$, and $* * *$ denote statistical significance at $10 \%, 5 \%$, and $1 \%$ levels, respectively. 
Table A.3. Differences pre- and post-tsunami in aggregate bank lending between affected and unaffected provinces: artificially designated tsunami dates

\begin{tabular}{|c|c|c|c|c|}
\hline Dependent variable: Loan growth & $(1)$ & $(2)$ & $(3)$ & $(4)$ \\
\hline Loan in severely affected $x$ post-tsunami & $\begin{array}{c}-0.011 \\
(0.010)\end{array}$ & $\begin{array}{c}-0.011 \\
(0.010)\end{array}$ & $\begin{array}{c}0.010 \\
(0.009)\end{array}$ & $\begin{array}{c}0.012 \\
(0.009)\end{array}$ \\
\hline Loan in mildly affected $x$ post-tsunami & $\begin{array}{l}-0.006 \\
(0.006)\end{array}$ & $\begin{array}{l}-0.007 \\
(0.006)\end{array}$ & $\begin{array}{c}0.002 \\
(0.003)\end{array}$ & $\begin{array}{c}0.004 \\
(0.004)\end{array}$ \\
\hline Bank branch & $\begin{array}{c}0.000 \\
(0.013)\end{array}$ & $\begin{array}{l}-0.012 \\
(0.016)\end{array}$ & $\begin{array}{c}-0.004 \\
(0.016)\end{array}$ & $\begin{array}{l}-0.005 \\
(0.018)\end{array}$ \\
\hline Deposit & $\begin{array}{c}0.100 \\
(0.065)\end{array}$ & $\begin{array}{l}0.129 * \\
(0.068)\end{array}$ & $\begin{array}{c}0.080 \\
(0.050)\end{array}$ & $\begin{array}{c}0.095 \\
(0.063)\end{array}$ \\
\hline Trend & $\begin{array}{c}0.835 * * * \\
(0.072)\end{array}$ & $\begin{array}{c}0.740 * * * \\
(0.155)\end{array}$ & $\begin{array}{c}0.847 * * * \\
(0.067)\end{array}$ & $\begin{array}{c}0.705 * * * \\
(0.158)\end{array}$ \\
\hline Observations & 1,650 & 1,650 & 1,650 & 1,650 \\
\hline R-squared & 0.260 & 0.272 & 0.244 & 0.250 \\
\hline Province fixed effects & Yes & Yes & Yes & Yes \\
\hline Month fixed effects & No & Yes & No & Yes \\
\hline
\end{tabular}

Notes: This table reports the difference-in-differences in lending between affected and unaffected provinces using artificial tsunami dates. The dependent variable is loan growth measured as the percentage change in aggregate bank loans in province $\mathrm{p}$ between month $\mathrm{t}$ and $(\mathrm{t}-1)$. The main independent variable of interest is the interaction between the tsunami-affected provinces and the months following the artificial tsunami date as shown in Equation (2). The tsunami date is falsified to have occurred one year (in December 2003) (results in Column 1 and 2) and two years (in December 2002) (results Column 3 and 4) before the actual tsunami date. We narrow the time horizon down to 22 months (from February 2003 to November 2004 inclusively) for the fictional event in December 2003 to avoid potential effects of the real tsunami that occurred in December 2004. Robust standard errors clustered at province level are in parentheses. *, **, and *** denote statistical significance at $10 \%, 5 \%$, and $1 \%$ levels, respectively. 
Table A.4. Differences pre- and post-tsunami in aggregate bank lending between affected and unaffected provinces: artificially designated affected provinces

\begin{tabular}{lcccc}
\hline Dependent variable: Loan growth & $(1)$ & $(2)$ & $(3)$ & $(4)$ \\
\hline Loan in severely affected x post-tsunami & 0.004 & $0.009^{*}$ & 0.002 & 0.006 \\
& $(0.006)$ & $(0.005)$ & $(0.005)$ & $(0.005)$ \\
Loan in mildly affected x post-tsunami & -0.004 & 0.003 & 0.001 & 0.006 \\
& $(0.013)$ & $(0.013)$ & $(0.008)$ & $(0.008)$ \\
Bank branch & $0.039^{*}$ & $0.085^{* * *}$ & $0.040^{*}$ & $0.084^{* * *}$ \\
& $(0.023)$ & $(0.030)$ & $(0.023)$ & $(0.031)$ \\
Deposit & 0.032 & 0.012 & 0.032 & 0.012 \\
& $(0.026)$ & $(0.037)$ & $(0.026)$ & $(0.037)$ \\
Trend & $0.623 * * *$ & $0.768^{* * *}$ & $0.622^{* * *}$ & $0.761 * * *$ \\
& $(0.134)$ & $(0.244)$ & $(0.133)$ & $(0.243)$ \\
Observations & 1,800 & 1,800 & 1,800 & 1,800 \\
R-squared & 0.211 & 0.229 & 0.210 & 0.229 \\
Province fixed effects & Yes & Yes & Yes & Yes \\
Month fixed effects & No & Yes & No & Yes \\
\hline
\end{tabular}

Notes: This table reports the difference-in-differences in lending between affected and unaffected provinces using artificial tsunami-affected provinces. The dependent variable is loan growth measured as the percentage change in aggregate bank loans in province $\mathrm{p}$ between month $\mathrm{t}$ and $(\mathrm{t}-1)$. The main independent variable of interest is the interaction between the artificial tsunami-affected provinces and the months following the actual tsunami date as shown in Equation (2). In this robustness test, the affected provinces are assigned incorrectly while the actual date remains unchanged. We first artificially designate provinces that share borders with the actual tsunami-affected provinces as affected. The results are reported in Column 1 and 2. This designation allows us to see if there are spill-over effects from potential shocks within the affected region other than the tsunami. Second, we assign randomly 75 provinces into three groups of severely affected, mildly affected and unaffected. The results are reported in Column 3 and 4 (this assignment is designed to detect if there are shocks that affect bank lending beyond the province affected by the tsunami). Robust standard errors clustered at province level are in parentheses. $*, * *$, and $* * *$ denote statistical significance at $10 \%, 5 \%$, and $1 \%$ levels, respectively. 
Table A.5. Differences pre- and post-tsunami in aggregate bank lending between affected and unaffected provinces: collapsed time periods

\begin{tabular}{lcc}
\hline Dependent variable: Loan growth & $(1)$ & $(2)$ \\
\hline Loan in affected provinces x post-tsunami & $-0.015^{* *}$ & $(0.007)$ \\
Loan in severely affected x post-tsunami & & $(0.011)$ \\
& & $-0.004^{* *}$ \\
Loan in mildly affected x post-tsunami & $(0.002)$ \\
Bank branch & $0.006^{* * *}$ & $0.006^{* * *}$ \\
& $(0.001)$ & $(0.001)$ \\
Deposit & 0.099 & 0.176 \\
& $(0.235)$ & $(0.193)$ \\
Trend & 0.183 & 0.164 \\
Observations & $(0.182)$ & $(0.183)$ \\
R-squared & 150 & 150 \\
Province fixed effects & 0.254 & 0.300 \\
Month fixed effects & No & No \\
\hline
\end{tabular}

Notes: This table reports the difference-in-differences in bank lending in all-affected, mildly-affected and severely-affected against unaffected provinces. The dependent variable is loan growth which is the average of the percentage change in aggregate bank loans in province $\mathrm{p}$ of the 12 months pre- and post-tsunami period separately. The main independent variable of interest is the interaction between the tsunami-affected provinces and the months following the tsunami. The estimation is based on Equation (1) (results in Column 1) and Equation (2) (results in Column 2). Robust standard errors clustered at province level are in parentheses. *, **, and *** denote statistical significance at $10 \%, 5 \%$, and $1 \%$ levels, respectively. 
Table A.6. Differences pre- and post-tsunami in aggregate bank lending between affected and unaffected provinces using neighbouring provinces as a control group

\begin{tabular}{lcccccc}
\hline $\begin{array}{l}\text { Dependent variable: Loan } \\
\text { growth }\end{array}$ & $(1)$ & $(2)$ & $(3)$ & $(4)$ & $(5)$ & $(6)$ \\
\hline Loan in severely affected x post- & $-0.050^{* * *}$ & $-0.043^{* *}$ & $-0.058^{* * *}$ & $-0.050^{* *}$ & $-0.073^{* * *}$ & $-0.069^{* * *}$ \\
tsunami & $(0.016)$ & $(0.016)$ & $(0.019)$ & $(0.019)$ & $(0.019)$ & $(0.022)$ \\
Loan in mildly affected x post- & -0.004 & 0.006 & 0.004 & $0.014^{*}$ & $0.014^{*}$ & $0.022^{* *}$ \\
tsunami & $(0.003)$ & $(0.007)$ & $(0.003)$ & $(0.007)$ & $(0.007)$ & $(0.009)$ \\
Bank branch & $0.132^{* * *}$ & $0.158^{* * *}$ & $0.163^{* *}$ & $0.187^{* *}$ & $0.215^{* *}$ & $0.270^{* *}$ \\
& $(0.041)$ & $(0.051)$ & $(0.061)$ & $(0.075)$ & $(0.085)$ & $(0.105)$ \\
Deposit & -0.200 & $-0.426^{*}$ & $-0.391^{*}$ & $-0.713^{* * *}$ & $-0.585^{*}$ & $-0.864^{* * *}$ \\
& $(0.145)$ & $(0.206)$ & $(0.198)$ & $(0.225)$ & $(0.283)$ & $(0.242)$ \\
Trend & $0.686^{* * *}$ & - & $0.751^{* * *}$ & - & $0.915^{* *}$ & - \\
& $(0.218)$ & & $(0.244)$ & & $(0.344)$ & \\
\hline Observations & 336 & 336 & 252 & 252 & 168 & 168 \\
R-squared & 0.308 & 0.338 & 0.315 & 0.351 & 0.377 & 0.402 \\
Province fixed effects & Yes & Yes & Yes & Yes & Yes & Yes \\
Month fixed effects & No & Yes & No & Yes & No & Yes \\
\hline
\end{tabular}

Notes: This table reports the difference-in-differences in lending between affected and unaffected provinces using unaffected provinces in Southern region as a control group. Six out of 14 provinces in this region are affected by the tsunami. As a consequence, the control group includes eight provinces. The dependent variable is loan growth measured as the percentage change in aggregate bank loans in province $p$ in Southern region between month $t$ and $(\mathrm{t}-1)$. The main independent variable of interest is the interaction between the tsunami-affected provinces and the months following the tsunami. The estimation is based on 24-month (results in Column 1 and 2); 18-month (results in Column 3 and 4) and 12-month time horizon (results in Column 5 and 6) around the tsunami date as shown in Equation (2). Robust standard errors clustered at province level are in parentheses. *, **, and *** denote statistical significance at $10 \%, 5 \%$, and $1 \%$ levels, respectively. 
Table A.7. Differences pre- and post-tsunami in aggregate bank lending between affected and unaffected provinces using the propensity scores matched sample as a control group

\begin{tabular}{lcccccc}
\hline $\begin{array}{l}\text { Dependent variable: Loan } \\
\text { growth }\end{array}$ & $(1)$ & $(2)$ & $(3)$ & $(4)$ & $(5)$ & $(6)$ \\
\hline Loan in severely affected x post- & $-0.079^{* * *}$ & $-0.064^{* * *}$ & $-0.099^{* * *}$ & $-0.086^{* * *}$ & $-0.103^{* * *}$ & $-0.096^{* * *}$ \\
tsunami & $(0.005)$ & $(0.004)$ & $(0.006)$ & $(0.008)$ & $(0.020)$ & $(0.015)$ \\
Loan in mildly affected x post- & -0.004 & $0.011^{* *}$ & 0.002 & $0.011^{* *}$ & 0.023 & $0.025^{*}$ \\
tsunami & $(0.003)$ & $(0.003)$ & $(0.002)$ & $(0.004)$ & $(0.018)$ & $(0.011)$ \\
Bank branch & $0.322^{*}$ & $0.472^{* *}$ & $0.673^{*}$ & $0.853^{* *}$ & $0.571^{* *}$ & $0.755^{* *}$ \\
& $(0.143)$ & $(0.121)$ & $(0.275)$ & $(0.272)$ & $(0.176)$ & $(0.275)$ \\
Deposit & $-0.278^{*}$ & $-0.895^{*}$ & $-0.364^{* *}$ & $-0.865^{*}$ & -0.700 & $-1.158^{*}$ \\
& $(0.132)$ & $(0.374)$ & $(0.141)$ & $(0.371)$ & $(0.387)$ & $(0.550)$ \\
Trend & 0.888 & 1.211 & 1.010 & 1.196 & 1.393 & 1.310 \\
& $(0.503)$ & $(0.814)$ & $(0.514)$ & $(0.835)$ & $(0.932)$ & $(0.909)$ \\
\hline Observations & 144 & 144 & 108 & 108 & 72 & 72 \\
R-squared & 0.322 & 0.400 & 0.379 & 0.435 & 0.414 & 0.458 \\
Province fixed effects & Yes & Yes & Yes & Yes & Yes & Yes \\
Month fixed effects & No & Yes & No & Yes & No & Yes \\
\hline
\end{tabular}

Notes: This table reports the difference-in-differences in lending using a matched sample between affected and unaffected provinces. The dependent variable is loan growth measured as the percentage change in aggregate bank loans in province $\mathrm{p}$ between month $\mathrm{t}$ and $(\mathrm{t}-1)$. The main independent variable of interest is the interaction between the tsunami-affected provinces and the months following the tsunami. In this robustness test, we employ a propensity score matching algorithm to identify matches between provinces that were affected by the tsunami with provinces that were not. We first estimate a probit model based on our original sample of 75 provinces in the month immediately before the tsunami. The dependent variable equals one if the province was affected by the tsunami and zero otherwise. The probit model includes province-variant variables similar to our baseline model (Equation 2). However, the variable 'trend' is defined as the average growth of loans over three months preceding the tsunami (in order to help satisfy the parallel trend assumption). We then use the predicted propensity scores and conduct a one-to-one nearest-neighbour matching without replacement to match the tsunami-affected provinces with unaffected provinces. The differences in propensity scores are set to be less than 0.01 . After matching, we have three matched pairs of provinces (the affected provinces are Phangnga, Ranong and Trang). We then re-run our estimations on the matched sample using Equation (2). The estimation is based on 24-month (results in Column 1 and 2), 18-month (results in Column 3 and 4) and 12-month time horizons (results in Column 5 and 6) around the tsunami date. Robust standard errors clustered at province level are in parentheses. *, **, and $* * *$ denote statistical significance at $10 \%, 5 \%$, and $1 \%$ levels, respectively. 